\title{
Plutonium and americium behaviour in soil-vegetation cover of natural and semi-natural ecosystems
}

\author{
G. Sokolik, S. Leinova and T.G. Ivanova \\ Belarusian State University, Radiochemistry Laboratory, \\ F. Skoriny Ave, 4, 220050 Minsk, Belarus
}

\begin{abstract}
The results of investigations of transuranic elements $\left({ }^{239,240} \mathrm{Pu}\right.$ and $\left.{ }^{241} \mathrm{Am}\right)$ behaviour in the soil-vegetation cover of natural and semi-natural ecosystems in the regions of Belarus contaminated as a result of Chernobyl accident have been summarised. The parameters of plutonium and americium vertical migration have been estimated for typical soil varieties; the radionuclides accumulation coefficients have been defined for dominating species of meadow and forest vegetation. The dynamics of change in physico-chemical state of plutonium and americium (the share and geochemical stability of "hot" particles, the ratio between fixed and mobile forms) has been analysed in various types of soils in the post-chernobyl period. It was established that the content of exchangeable ${ }^{279.240} \mathrm{Pu}$ and ${ }^{211} \mathrm{Am}$ does not exceed $12.5 \%$, the largest part of radionuclides is in fixed form in composition of soil humus and organo-mineral components. The linear rate of vertical migration of plutonium and americium in soils is 0.14-1.25 cm/year. Simultaneous interaction of different agrochemical parameters and natural conditions masks the influence of individual soil properties on migration rate, but the correlation with humidity has been reviled. The accumulation coefficients of americium in the system "soil-plant" are 1.2 . 4 times higher that those for plutonium. The method of reduction in the bioavailability of transuranic elements has also been proposed.
\end{abstract}

\section{INTRODUCTION}

Of all the sources of transuranic elements (TUE) contamination of the territory of Belarus the accident on Chernobyl NPP was the most significant one. Before the accident the soil contamination level had been less than $50 \mathrm{~Bq} / \mathrm{m}^{2}$, but afterwards the contamination level of the upper layer of soil reached $1.1 \times 10^{5}$ $\mathrm{Bq} / \mathrm{m}^{2}$ on the south of Belarus [1]. Of all $\alpha$-emitting TUE ${ }^{239,240} \mathrm{Pu}$ and ${ }^{241} \mathrm{Am}$ are at present time the most important ones. Because of their high toxicity, long period of half-decay and biological half-removal their role should be taken into account when developing countermeasures on rehabilitation of affected territory. That dictates the necessity in careful studies of plutonium and americium behaviour in the environment and in particular in natural and semi-natural ecosystems, which are more critical in comparison to agroecosystems. The most dangerous consequences of contamination are conditioned by the biological migration of radionuclides. The rate of migration processes in natural and semi-natural ecosystems are defined by many factors; the landscape and geochemical peculiarities of area, the type of soil, the specie composition of biocenose and the physico-chemical state of radionuclides in soil cover are among them.

\section{OB.JECTS AND METHODS OF INVESTIGATION}

The investigations of migration ability and physico-chemical state of TUE in soil cover have been implemented during $1987-2000$ on control stationaries situated at different distance from CNPP $(12-250 \mathrm{~km})$. As is seen from the Table 1 investigated stationeries are typical for the affected regions of Belarus: they include the main geomorphological levels (low floodplain, terrace, watershed plateau), the main types of soil (soddy-podzolic, soddy, peaty) and main kinds of natural and semi-natural ecosystems (forest and meadows). The mean fallout density of TUE varies in the wide interval: $80-28000 \mathrm{~Bq} / \mathrm{m}^{2}$. On the base of calculated isotope ratio ${ }^{238} \mathrm{Pu} /{ }^{239,240} \mathrm{Pu}$ (which is $0.48+0.12$ ) it is possible to conclude that radioactive fallout in all investigated stationaries has Chemobyl origin.

The content of TUE has been defined after chemical treatment of ashed soil or biological samples, ion-exchange separation of plutonium and americium and their purification from trace contaminants and 
accompanying radionuclides on resin; $\alpha$-activity of plutonium and americium has been registered using ALPHA-KING-676 A spectrometer (relative error - 5-50\%). The occurrence forms of plutonium and americium in soil have been investigated using method of sequential selective extraction with various chemical agents. The content of "hot" particles in soil samples has been defined using radiography method, its sensitivity allows us to detect "hot" particles with activity $10^{-2} \mathrm{~Bq}$ and more $[2,3]$.

Table 1. The characteristics of control stationaries

\begin{tabular}{|c|c|c|c|c|}
\hline $\begin{array}{l}\text { Stntion- } \\
\text { ary }\end{array}$ & $\begin{array}{l}\text { Location and dis- } \\
\text { tance from CNPP, } \\
\mathrm{km}\end{array}$ & Place in the lanscape & Type of the soil & \begin{tabular}{|l}
$\begin{array}{l}\text { Mean density of } \\
239,200 \mathrm{Pu} \\
\mathrm{Bg} / \mathrm{m}^{2}\end{array}$ \\
fallout,
\end{tabular} \\
\hline S-1 & $\begin{array}{l}\text { Khoiniki district, } \\
\text { Gomel region, } 53\end{array}$ & Low flood-plain (meadow) & $\begin{array}{l}\text { alluvial soddy sandy } \\
\text { loam }\end{array}$ & $730 \pm 100$ \\
\hline S-2 & PSRER', 20 & Low flood-plain (meadow) & $\begin{array}{l}\text { alluvial soddy sandy } \\
\text { loam }\end{array}$ & $4790 \pm 1000$ \\
\hline SP-3 & $\begin{array}{l}\text { Khoiniki district, } \\
\text { Gomel region, } 40\end{array}$ & $\begin{array}{l}\text { Terrace above the flood- } \\
\text { plain (forest) }\end{array}$ & soddy-podzolic sand & $970 \pm 240$ \\
\hline $\mathrm{P}-4$ & $\begin{array}{l}\text { Khoiniki district, } \\
\text { Gomel region, } 46\end{array}$ & $\begin{array}{l}\text { Lower part of terrace above } \\
\text { the flood-plain (meadow) }\end{array}$ & peaty mineralised & $1000 \pm 100$ \\
\hline SP-5 & PSRER, 20 & $\begin{array}{l}\text { Terrace above the flood- } \\
\text { plain (meadow) }\end{array}$ & soddy-podzolic sand & $6200 \pm 600$ \\
\hline SP-6 & $\begin{array}{l}\text { Khoiniki district, } \\
\text { Gomel region, } 48\end{array}$ & \begin{tabular}{|l}
$\begin{array}{l}\text { Watershed } \\
\text { (meadow) }\end{array}$ \\
\end{tabular} & $\begin{array}{l}\text { soddy-podzolic sandy } \\
\text { loam }\end{array}$ & $1400 \pm 300$ \\
\hline P-7 & PSRER, 20 & $\begin{array}{l}\text { Lower part of terrace above } \\
\text { the flood-plain (meadow) }\end{array}$ & peaty gley & $9070 \pm 400$ \\
\hline SP-8 & PSRER, 12 & $\begin{array}{l}\text { Terrace above the flood- } \\
\text { plain (meadow) }\end{array}$ & $\begin{array}{l}\text { soddy-podzolic sandy } \\
\text { loam }\end{array}$ & $28000 \pm 7000$ \\
\hline P-9 & PSRER, 30 & $\begin{array}{l}\text { Lower part of terrace above } \\
\text { the floodplain (forest) }\end{array}$ & peaty-bog & $5400 \pm 110$ \\
\hline SP-10 & PSRER, 17 & $\begin{array}{l}\text { Terrace above the flood- } \\
\text { plain (meadow) }\end{array}$ & soddy-podzolic sand & $4000 \pm 400$ \\
\hline P-11 & $\begin{array}{l}\text { Cherikov } \\
\text { Mogilev } \\
250\end{array}$ & $\begin{array}{l}\text { Swamped floodplain } \\
\text { (meadow) }\end{array}$ & alluvial peaty gley & $80+15$ \\
\hline S-20 & $\begin{array}{l}\text { Korma district, } \\
\text { Gomel region, } 200\end{array}$ & Low flood-plain (meadow) & $\begin{array}{lll}\begin{array}{l}\text { alluvial soddy } \\
\text { loam }\end{array} & \\
\end{array}$ & $60 \pm 10$ \\
\hline SP-27 & $\begin{array}{l}\text { Korma district, } \\
\text { Gomel region, } 200\end{array}$ & \begin{tabular}{|l|}
$\begin{array}{l}\text { Slope of watershed plateau } \\
\text { (forest) }\end{array}$ \\
\end{tabular} & $\begin{array}{l}\begin{array}{l}\text { soddy-podzolic sandy } \\
\text { loam }\end{array} \\
\end{array}$ & $170 \pm 35$ \\
\hline
\end{tabular}

- Pollesye State radioecological reservoir

\section{RESULTS AND DISCUSSION}

Investigations were conducted in the following directions:

- character of vertical redistribution of TUE in mineral and organic soils;

- content of mobile and fixed occurrence forms of radionuclides in soil of different genesis;

- biological availability of plutonium and americium, peculiarities of transfer of TUE into forest and meadow vegetation.

Investigation of plutonium and americium behaviour has shown that migration properties of radionuclides in soil of different types are weak. The main part of TUE is concentrated in upper (0-10)-cm layers of soil in mineral as well as organic soils. The Figure 1 shows the results of vertical redistribution of plutonium and americium in typical forest and meadow landscapes situated at different distance from CNPP.

The analysis of the data shows that for vertical redistribution of TUE in soddy-podzolic sandy (SP-3) and sandy loam (SP-27) soils of forest stationaries the sharp decrease in the radionuclide content down the soil profile is characteristic: deepening of only $5 \mathrm{~cm}$ leads to tenfold changes in specific activity. For example, in the soil of stationary SP-27 the content of TUE in $(0-1)-\mathrm{cm}$ and (5-6)-cm soil layers makes 40 
and $2 \%$ of summary content of radionuclides in soil respectively. The low rates of plutonium and americium vertical migration are caused by the accumulation effect of forest litter.

As a rule, the slow migration of TUE is characteristic also for the mineral soils of meadow stationaries. For example, in soddy sandy loam soil S-1 practically all the radionuclides $(75 \%)$ are concentrated in upper (0-5)-cm layers. But in meadow soddy soils more intense migration processes of TUE and their removal to the underlying layers may nevertheless occur, as has been stated for stationary S-20. In this stationary the long flood period is observed, it promotes the high moistening regime of the soil and as a result the intensive radionuclide migration capacity.
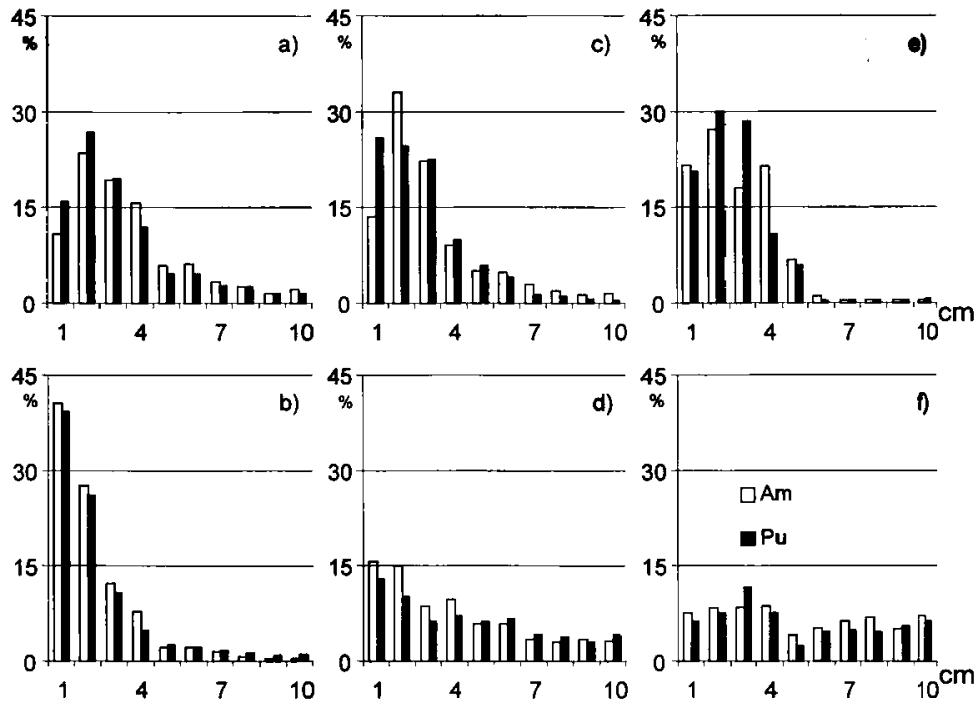

Figure 1. The vertical distribution of TUE along profile of soils (1995): a) SP-3 (40km); b) SP-27 (200 km); c) S-1 (53 km); d) S-20 (200 km); e) P-4 (46 km); f) P-1] (250 km)

The vertical redistribution of plutonium and americium in organic soils is shown using as example two stationaries P-4 and P-11. The chosen stationaries characterise the conditions of meliorated meadow ( $\mathrm{P}-4$ is a dried massif in the lower part of terrace above the floodplain) and flooded meadow (P-11 is a plot near swamped floodplain). The layer-by-layer distribution of TUE in the profile of these soils differs significantly. In the dry peat (P-4) the sharp decrease in the radionuclides concentration with depth is observed. And contrary, in swamped peaty soil of $\mathrm{P}-11$ the pracess of vertical migration passes intensively enough: plutonium and americium removal on the depth below $10 \mathrm{~cm}$ was more that $30 \%$ and in meliorated peaty soil at the same depth only $2 \%$ of summary supply of radionuclides is concentrated. Thus, the water regime of the soils has significant effect on the mobility of TUE in mineral as well as organic soils.

Table 2 shows the linear migration rates calculated on the base of many-years studding of the shift of the centre of radionuclides summary content [4]. It seems to be impossible at the present moment to differentiate strictly the rate parameters of TUE according to the soil type due to the multiplicity of factors simultaneously influencing the processes of radionuclides transfer in the natural conditions. Comparative analysis has been done to examine the correlation between migration rate of radionuclides and physical clay, organic carbon, potassium and calcium content, cation exchange capacity, acidity. The influence of 
different agrochemical parameters in total masks the effect of individual soil property on migration rate. Only the dependence between the rate of radionuclides deepening and humidity of soil has been reviled. Thus, the value of rate of linear migration of TUE in the hydromorphous soddy soil of flooded meadow (S-20) is about 3-5 times higher than that in automorphous soddy-podzolic soils (SP-3, SP-5 and SP-27); in swamped peaty soil (P-I 1 ) it is 4 times higher than that in dried peat (P-4).

The differences in the migration rate parameters of radionuclides observed in the soils of the same type (e.g. S-1 and S-2, SP-3 and SP-5) are possibly caused by the character of radioactive fallouts. For the similar soil varieties the more intensive migration of radionuclides has been observed on the control stationaries with lower share of the fuel component. Thus, the linear migration rate of plutonium in meadow soddy sandy-loam soils S-1 (the share of the fuel component in initial fallout $64 \%$ ) and S-2 (90\%) is 0.30 and $0.14 \mathrm{~cm} /$ year correspondingly, and for americium -0.35 and $0.25 \mathrm{~cm} /$ year [3].

Table 2. The linear migration rate of TUE in soils

\begin{tabular}{|c|c|c|}
\hline \multirow{2}{*}{ Stationary } & \multicolumn{2}{|c|}{ Mean migration rate, $\mathrm{cm} /$ year } \\
\cline { 2 - 3 } & ${ }^{239,240} \mathrm{Pu}$ & ${ }^{24} \mathrm{Am}$ \\
\hline S-1 & $\mathbf{0 . 3 0 \pm 0 . 0 5}$ & $0.35 \pm \mathbf{0 . 0 4}$ \\
\hline S-2 & $\mathbf{0 . 1 4} \pm 0.02$ & $0.25 \pm \mathbf{0 . 0 4}$ \\
\hline SP-3 & $\mathbf{0 . 4 2 \pm 0 . 0 8}$ & $0.46 \pm \mathbf{0 . 0 8}$ \\
\hline SP-5 & $0.25 \pm 0.05$ & $0.30 \pm \mathbf{0 . 0 6}$ \\
\hline P-4 & $\mathbf{0 . 2 6 \pm 0 . 0 5}$ & $0.28 \pm \mathbf{0 . 0 7}$ \\
\hline P-7 & $\mathbf{0 . 3 1 \pm 0 . 0 8}$ & $0.35 \pm \mathbf{0 . 0 7}$ \\
\hline P-11 & $1.15 \pm 0.20$ & $\mathbf{1 . 0 6 \pm 0 . 1 5}$ \\
\hline S-20 & $1.24 \pm 0.20$ & $1.25 \pm \mathbf{0 . 2 5}$ \\
\hline SP-27 & $0.44 \pm 0.18$ & $0.41 \pm \mathbf{0 . 0 7}$ \\
\hline
\end{tabular}

Together with vertical distribution of plutonium and americium in the soil profile the migration ability of radionuclides could be estimated on the base of their physico-chemical state in the soil. Originally TUE were in the most part in the composition of "hot" particles with matrix consisted of uranium oxides of various oxidation degrees. The investigations have shown that dispersion and chemical destruction of "hot" particles have passed during the post-accident period in the natural conditions under the influence of various physico-chemical processes and as a consequence the content of "hot" particles in soils and their size have decreased significantly. Now the density of "hot" particles on investigated soils is not more than $1.10^{3}$ per $1 \mathrm{~m}^{2}$, that in three order less than in 1987 . It has been established that the rate of destruction of "hot" particles is defined by physico-chemical properties of the particles and natural conditions, where these particles happened to be, as well. The more is the acidity of the soil media and the more is the share of organic components in the soil, the more intensive processes of destruction of "hot" particles are observed $[3,5]$.

After decomposition of "hot" particles released TUE react with the components of soil adsorbing complex, their physico-chemical state being transformed in that process. Though the main quantity of plutonium and americium during post-accident period remains to be in the heavy-mobile state. It is due to the fact that fixation of radionuclides in the matrix of "hot" particles is substituted by their fixation by the components of soil complex. The data in the Table 3 show the relative content of mobile and heavymobile forms in the main types of soil. During all the period of investigations the main part of radionuclides remains in the heavy-mobile state (fractions $A 2+A 3+A 4$ ), being fixed by soil humus, amorphous iron and aluminum hydroxides, and also by organo-mineral components, clay minerals and in the structure of "hot" particles. The content of mobile exchangeable form (fraction Al) of plutonium and americium does not exceed 9.2 and $12.5 \%$ correspondingly. The values of content of mobile form vary from year to year due to wide heterogeneity of radioactive fallout, soil media, variability of environment conditions. According to the decrease of the mean content of mobile forms of TUE the soils can be ranged in the following order: soddy-podzolic, soddy, peat. The content of mobile americium in mineral types of soil is a little higher than that of plutonium.

Because there are many soils with high acidity in Belarus the acid-soluble form of radionuclides (fraction A2) is of interest as the potentially mobile one. Insofar as the acid media is formed in the very 
vicinity of surface of root filaments of plants, this could be the base to count this form as the biologically available one. It was established that the content of americium in acid-soluble form (A2) is higher than that of plutonium: in mineral soils it reaches $88 \%$, but at the same time it is only $44 \%$ for plutonium; in peaty soils the share of acid-soluble plutonium and americium is 34 and $14 \%$ correspondingly. So, the increase of acidity of soil promotes the destruction of complex compounds of americium with organic and organo-mineral soil components in more degree than that for plutonium $[2,6]$.

Table 3. The relative content of mobile and heavy-mobile forms of ${ }^{29,240} \mathrm{Pu}$ and ${ }^{241} \mathrm{Am}$ in (0-5)-cm soil layers

\begin{tabular}{|c|c|c|c|c|c|}
\hline \multirow[t]{2}{*}{$\begin{array}{c}\text { Statio } \\
\text { nary }\end{array}$} & \multirow[t]{2}{*}{ Year } & \multicolumn{2}{|c|}{$\begin{array}{l}\text { Mobile forms } \\
\text { (A1)* }\end{array}$} & \multicolumn{2}{|c|}{$\begin{array}{l}\text { Heavy-mobile forms } \\
\text { (A2+A3+A4) }\end{array}$} \\
\hline & & ${ }^{239,280} \mathrm{Pu}, \%$ & ${ }^{2 d} \mathrm{Am}, \%$ & $239,240 \mathrm{Pu}, \%$ & ${ }^{2 \pi} \mathrm{Am}, \%$ \\
\hline \multirow{3}{*}{ S-2 } & 1992 & $2.9 \pm 0.4$ & $5.0 \pm 0.8$ & 97.1 & 95.0 \\
\hline & 1995 & $3.3 \pm 0.5$ & $3.9 \pm 0.6$ & 96.7 & 96.1 \\
\hline & 1998 & $3.0 \pm 0.5$ & $4.5 \pm 0.7$ & 97.0 & 95.5 \\
\hline \multirow{4}{*}{ SP-5 } & 1992 & $3.9 \pm 0.6$ & $7.0 \pm 1.1$ & 96.1 & 93.0 \\
\hline & 1995 & $9.2 \pm 1.4$ & $10.1 \pm 1.5$ & 90.8 & 89.9 \\
\hline & 1998 & $7.3 \pm 1.1$ & $11.1 \pm 1.7$ & 92.7 & 88.9 \\
\hline & 1999 & $4.5 \pm 0.7$ & $10.7 \pm 1.6$ & 95.5 & 89.3 \\
\hline \multirow{2}{*}{ SP-10 } & 1992 & $6.0 \pm 0.9$ & $12.5 \pm 1.9$ & 94.0 & 87.5 \\
\hline & 1993 & $3.7 \pm 0.7$ & $10.1 \pm 1.8$ & 96.3 & 88.9 \\
\hline \multirow{3}{*}{$P-4$} & 1992 & $1.0 \pm 0.2$ & - & 99.0 & - \\
\hline & 1993 & $0.7 \pm 0.2$ & $2.8 \pm 0.7$ & 99.3 & $9 \overline{97.2}$ \\
\hline & 1995 & $1.1 \pm 0.3$ & $=$ & 98.9 & - \\
\hline \multirow{3}{*}{ P-7 } & 1992 & $0.5 \pm 0.1$ & $0.4 \pm 0.2$ & 99.5 & 99.6 \\
\hline & 1995 & $3.5 \pm 0.5$ & $3.6 \pm 0.5$ & 96.5 & 96.4 \\
\hline & 1999 & $0.7 \pm 0.1$ & $0.8 \pm 0.1$ & 99.3 & 99.2 \\
\hline
\end{tabular}

* Al - exchangeable, $1 \mathrm{~mol} / \mathrm{I} \mathrm{NH}_{4} \mathrm{Ac}$

$* \mathrm{~A} 2$ - acid-soluble, $1 \mathrm{~mol} / \mathrm{HCl}$

A3 - bound with relatively mobile humic and fulvic acids, $1 \mathrm{~mol} / 1 \mathrm{NaOH}+$ $0,05 \mathrm{~mol} / / \mathrm{Na}_{2} \mathrm{C}_{2} \mathrm{O}_{4}$

A4 - bound with heavy-mobile components of soil humus and mineral soil residuum, ashing $+7,5 \mathrm{~mol} / / \mathrm{HNO}_{3}$

The physico-chemical state of radionuclides in soil defines their biological availability. We have studied the transfer of TUE into biomass of grass vegetation of meadow and forest phytocenoses (Figure 2). It should be noted that the higher accessibility of TUE for uptake by plants of natural complexes in comparison with agricultural systems is observed due to existence of forest litter and sod (retaining radionuclides). The intake of TUE by vegetation has been assessed as the value of accumulation coefficient that is the ratio between the specific activity of TUE in plant and in (0-5)-cm soil layer.

Though the direct dependence between density of soil contamination and concentration of TUE in vegetation is observed, the accumulation coefficients of radionuclides by plants do not depend on the density of contamination. The coefficients values are in the range $3 \times 10^{-3}-3 \times 10^{-2}$ for plutonium and $6 \times 10^{-3}$ $-7 \times 10^{-2}$ for americium and are defined by the type of soil and biological peculiarities of the vegetation. As is seen on the Figure 2, for the meadow grass vegetation growing on peaty soils the accumulation coefficients are lower than on soddy-podzolic and soddy soils. The greatest coefficients are characteristic for such species as carex and elytrigia repens. The results of investigation of soil to plant transfer of TUE conform with the data obtained from investigation of physico-chemical state of radionuclides. The minimum content of mobile forms is observed in organic peaty soils in comparison with mineral soils and this is explained by the fixing (complex-forming) capability of soil organic matter in regard to TUE.

The data presented show that all other factors being the same the accumulation coefficients of americium by grass vegetation is several times higher than that for plutonium in all cases considered. 


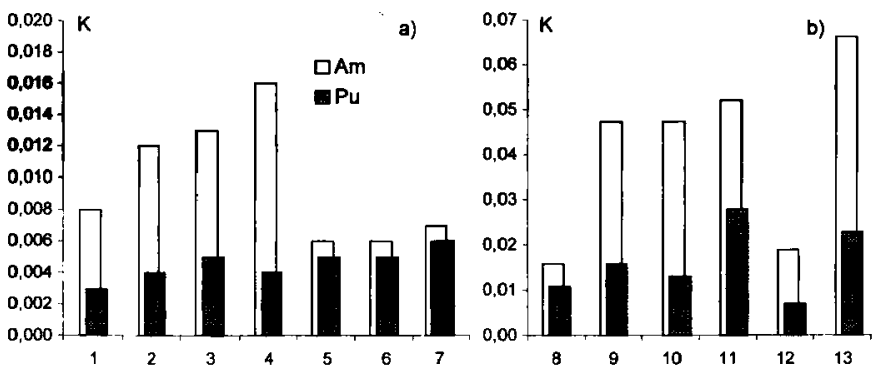

Figure 2. The coefficients of accumulation of plutonium and americium by various plants grown on a) organogenic soils: P-7 - conitum ( $/$ ), carex (2), poa (3), cirsium (4); P-9 - festuca pratensis (5), rhinanihus (6), urica (7)

b) mineral soils: SP-5 - corinephorus canesecus (8); SP-6 - dactulis glomerata (9), calamagrastis (10); SP-8 - elytrigia repens (I/); S-2 - dactulis glomerata (/2), carex (13).

\section{CONCLUSION}

The results of investigation of vertical migration, mobile and fixed state, bioavailability of TUE allow us to make a conclusion that one of the main ways to reduce TUE uptake by vegetation is the change in the physico-chemical properties of soil media directed toward the reduction in radionuclide mobility through change in their occurrence forms to the fixed one. Addition to soil of organic fertilizers forming difficultly soluble organo-mineral compounds with TUE promotes to reduction of radionuclides redistribution in the system "soil - plant". To reduce the biological mobility of TUE in mineral soil it is proposed to apply to the soil peat with a low content of water-soluble organic components. Enrichment of automorphous soddy-podzolic soils with peat creates the optimal for plants water-physical regime and also improves the fertility of the soil through thickening of the humus horizon. The method enables creation of highly productive and ecologically safe lands and can be used in natural ecosystems as well as agrarian complexes.

\section{References}

1. V.P. Mironov, V.P. Kudryshov, P.I. Ananich, V.V. Zuravkov, in Proceedings of the Internationa' Conference on Radioactivity after Nuclear Explosions and Accidents, Moscow, 2000, edited by Yu.A. Izrael (Hidrometoizdat, Sankt-Petersburg, 2000), Vol. 1, pp. 189-194.

2. G.A. Sokolik, S.L. Kilchitskaya, T.G. Ivanova, S.L. Leinova, N.V. Zhukovich, I.M. Kimlenko, News of the National Academy of Sciences of Belarus, Physics and Technical Series, 1 (2000) 142-148.

3. E.P. Petryaev, M. Belli, G.A. Sokolik, S.L. Leinova, V.V. Duksina, in Proceedings of the First International Conference on Radiological Consequences of the Chernobyl Accident. Minsk, 1996, edited by A. Karaoglou, G. Desmet, G.N. Kelly and H.G. Menzel (ECSC-EC-EAEC, BrusselsLuxembourg, 1996), pp. 543-547.

4. G. Arapis, E. Petrayev, E. Shagalova, O. Zhukova, G. Sokolik, T. Ivanova, J. Environ. Radioactivity. 34, 2 (1997) 171-185.

5. V.A. Kashparov, V.P. Protsak, N. Ahamdach, D. Stammose, J.M. Peres, V.I. Yoschenko, S.I. Zvarich, Journal of Nuclear Materials, 279 (2000) 225-233.

6. G.A. Sokolik, T.G. Ivanova, S.L. Leinova, S.V. Ovsiannikova, I.M. Kimlenko, Environ. Int. 26, 3 (2001) 183-187. 